\title{
Clindamycin-induced neuromuscular blockade
}

The purpose of this article is to report the case of a patient who developed prolonged neuromuscular block after a large dose of clindamycin (2400 mg). A 58-yr-old, $65 \mathrm{~kg}$ woman with severe rheumatoid arthritis was admitted for wrist arthrodesis. After d-tubocurarine $(3 \mathrm{mg}$ ) and fentanyl (1.5 $\mu \mathrm{g} \cdot \mathrm{kg}^{-1}$ ), anaesthesia was induced with thiopentone (4 $\mathrm{mg} \cdot \mathrm{kg}^{-1}$ ) followed by succinycholine $\left(1.5 \mathrm{mg} \cdot \mathrm{kg}^{-1}\right)$ and was maintained with $\mathrm{N}_{2} \mathrm{O}$ in $\mathrm{O}_{2}$ and isoflurane $(0.75-1.0 \%$ end iidal) and ventilation was controlled. No further neuromuscular relaxants were given although full return of neuromuscular activity in response to train-of-four and $100 \mathrm{~Hz}$ tetanic stimulation was observed after succinylcholine. An overdose of clindamycin (2400 mg, instead of the intended $600 \mathrm{mg}$ ) was given iv soon after the start of surgery. At the end of surgery, $75 \mathrm{~min}$ later, the patient made no attempt at spontaneous ventilation, was unresponsive to painful stimuli and naloxone $(0.2 \mathrm{mg}$ iv) was ineffective. Controlled ventilation was continued in the Recovery Room where neuromuscular testing showed a train-of-four ratio of 0.27 which improved to only 0.47 five minutes after calcium chloride $\left(1.5 \mathrm{mg} \cdot \mathrm{kg}^{-1} \dot{\mathrm{v}}\right)$, and to 0.62 afier edrophonium (20 mg) and neostigmine (2 $\mathrm{mg}$ ). Nine hours later the patient began to cough, the TOF had returned to 1.0 and two hours later the trachea was extubated and spontaneous ventilation was resumed. Large doses of clindamycin can induce profound, long-lasting neuromuscular blockade in the absence of non-depolarizing relaxants and after full recovery from succinylcholine has been demonstrated.

\section{Key words}

ANTIBIOTICS: clindamycin;

COMPLICATIONS: drug overdose, paralysis;

NEUROMUSCULAR FUNCTION: antibiotics;

PHARMACOLOGY: drug interactions.

From the Department of Anaesthesia, Vancouver Hospital and UBC, Rm 3200, 855 West 12th Avenue, Vancouver, BC V5Z $1 \mathrm{M} 9$.

Address correspondence to: Dr. Al Ahdal.

Accepted for publication 26th March, 1995.
Cette observation décrit une curarisation prolongée provoquée par une dose exagérée de clindamycine $(2400 \mathrm{mg}$ ). Une femme de 58 ans pesant $65 \mathrm{~kg}$ affectée d'une arthrite rhumatoïde grave est programmée pour une arthrodèse du poignet. Après $d$ tubocurarine $3 \mathrm{mg}$ et fentanyl $1,5 \mu \mathrm{g} \cdot \mathrm{kg}^{-1}$, l'anesthésie est induite avec du thiopentone $4 \mathrm{mg} \cdot \mathrm{kg}^{-1}$ suivi de succinylchlone $1,5 \mathrm{mg} \cdot \mathrm{kg}^{-1}$ et entretenue avec $\mathrm{N}_{2} \mathrm{O} / \mathrm{O}_{2}$ et isoflurane à la concentration téléexpiratoire de $0,75-1,0 \%$ en ventilation contrôlée. Elle ne reçoit pas de supplément de myorelaxant quoique la récupération complète de la succinylcholine évaluée par la stimulation au train de quatre (TOF) et au tétanos à $100 \mathrm{~Hz}$ soit évidente. Une dose exagérée de clindamycine $(2400$ $\mathrm{mg}$ plutôt que les $600 \mathrm{mg}$ prévus) avait été administrée dès le début de lintervention. $A$ la fin de la chirurgie, $75 \mathrm{~min}$ plus tard, la patiente ne fait aucun effort respiratoire, ne répond ni au stimulus douloureux ni au naloxone $0,2 \mathrm{mg} \mathrm{i}$. La ventilation contrôlée est continuée en salle de réveil où la stimulation produit un TOF à 0,27 qui ne remonte qu' $0,47 \%$ cinq minutes après du chlorure de calcium $1,5 \mathrm{mg} \cdot \mathrm{kg}^{-1}$, et à 0,62 après de l'édrophonium $20 \mathrm{mg}$ et de la néostigmine $2 \mathrm{mg}$. Neuf heures plus tard, la patiente commence à tousser, le TOF revient à 1,0 et deux heures plus tard la ventilation spontanée récupère et la trachée est extubée. Des doses élevées de clindamycine peuvent provoquer une curarisation profonde et de longue durée indépendante des non dépolarisants et après que la récupération complète de la succinylcholine ait été démontrée.

Clindamycin is a semi-synthetic, propylhygrinic acid derivative whose antimicrobial activity is mediated by its action on $50^{\mathrm{s}}$ subunit of bacterial ribosome leading to suppression of protein synthesis. There are several reports of its local anaesthetic ${ }^{1}$ and neuromuscular blocking actions. $^{2-5}$ In doses of $600-1200 \mathrm{mg}$ it has been shown to prolong the neuromuscular blocking actions of pancuronium, ${ }^{2}$ vecuronium ${ }^{3}$ but recovery from pipecuronium was not affected by a dose of $300 \mathrm{mg} .{ }^{4}$ There is uncertainty whether the block is reversible with calcium or with anticholinesterases although both have been recommended. ${ }^{5}$

The purpose of this report is to record a very prolonged neuromuscular block which occurred when an unintentional overdose of clindamycin was given to a patient 
who had received only a small defasciculating dose of d-tubocurarine ( $3 \mathrm{mg}$ ) and who demonstrated full clinical recovery from a single dose of succinylcholine before the clindamycin was administered. Calcium had no effect on the block and that recovery following anticholinesterases was minimal.

\section{Case report}

The patient was a 58 -yr-old, $65 \mathrm{~kg}$ woman with severe, widespread rheumatoid arthritis who was scheduled for arthrodesis of the left wrist under general anaesthesia. She had no signs or symptoms of cardiovascular or respiratory disease, and haematological and biochemical testing, ECG, CXR and cervical spine $x$-ray were all within normal limits. She was taking occasional nonsteroidal anti-inflammatory drugs for pain relief and prednisone, which she had been prescribed for two years, had been tapered and stopped one month before surgery. There was no evidence of steroid-induced myopathy. She had a history of skin allergy to penicillin. She had had several uneventful previous operations with general anaesthesia.

No premedication was given. Standard monitoring was with automatic BP, ECG, pulse oximetry, capnometry and ulnar nerve stimulation for neuromuscular monitoring (Dual Stim, Model NN-2CA, Lifetech Inc., Houston). After breathing oxygen from a face mask, d-tubocurarine $(3 \mathrm{mg})$ and fentanyl $(100 \mu \mathrm{g})$ were given $i v$. Three minutes later, anaesthesia was induced with thiopentone $(275 \mathrm{mg})$, followed by succinylcholine $(100 \mathrm{mg})$ to facilitate tracheal intubation using a $7 \mathrm{~mm}$ tube. Anaesthesia was maintained with nitrous oxide, $60-65 \%$ in oxygen supplemented with isoflurane (end-tidal concentration $0.75-1.0 \%$ ) but no additional opioids. Ventilation was controlled to maintain $\mathrm{PETCO}_{2}$ at $30-35 \mathrm{mmHg}$ but no further neuromuscular relaxants were given although full clinical recovery to train-of-four (TOF) and $100 \mathrm{~Hz}$ tetanic (TET) stimulation was demonstrated ten minutes after administration of succinylcholine: four equal twitches to TOF and sustained response to $100 \mathrm{~Hz}$ TET stimulation for five seconds with a current of $25-30 \mathrm{~mA}$.

Before the start of surgery, but after recovery from succinylcholine had been demonstrated, the surgeon requested thta clindamycin, $600 \mathrm{mg}$. be given. Consequently, four ampoules of clindamycin phosphate marked "150 mg," each containing four millilitres, were given $i v$ over $15 \mathrm{~min}$. Anaesthesia was uneventful and at the end of surgery, $75 \mathrm{~min}$ later, the anaesthetic agents were gradually withdrawn and the minute volume was reduced. However, the patient made no attempt at spontaneous ventilation, was unresponsive to painful stimuli and naloxone $(2 \times 0.1 \mathrm{mg})$ was ineffective, although $\mathrm{PETCO}_{2}$ had increased to $65 \mathrm{mmHg}$ and end-tidal isoflurane concentration was $<0.1 \%$. The endotracheal tube was left in position and controlled ventilation was continued in the Recovery Room. Thirty minutes later, clinical neuromuscular testing of TOF stimulation of the ulnar nerve (Dualstim nerve stimulator) showed weak visual and tactile responses with fade to TOF and TET, and post-TET facilitation, typical of profound non-depolarizing block. Formal neuromuscular testing was commenced. The clindamycin ampoules were re-examined and it was found that each contained four millilitres at a concentration of $150 \mathrm{mg} \cdot \mathrm{ml}^{-1}$. Thus, four times the intended dose had been given and it was assumed that the patient was demonstrating a clindamycin-induced neuromuscular block.

In the Recovery Room, surface electrodes were applied to the ulnar nerve at the wrist and the force of contraction of the adductor pollicis muscle was measured with a Grass FT-10 transducer (Grass Instruments, Quincy, Mass, USA). Supra-maximal stimulation with trains of stimuli of 0.1 msec duration and frequency of $2 \mathrm{~Hz}$ were applied to the ulnar nerve every $12 \mathrm{sec}$. Initially there was a weak response with TOF of 0.27 which improved to 0.47 after calcium chloride $\left(1.5 \mathrm{mg} \cdot \mathrm{kg}^{-1} \dot{i}\right)$, and to 0.53 after edrophonium $(20 \mathrm{mg})$ and atropine $(0.6 \mathrm{mg})$ and to 0.62 after neostigmine $(2 \mathrm{mg})$ and atropine (1 $\mathrm{mg}$ ).

Nine hours after the end of surgery the patient began to cough, TOF had returned to 1.0 , and two hours later the trachea was extubated and spontaneous ventilation was resumed. The patient was discharged three days later with no obvious sequelae although she did complain of generalised weakness for $24 \mathrm{hr}$ but this could not be detected clinically.

\section{Discussion}

The neuromuscular block in this patient was assumed to be the result of an overdose of clindamycin. Four times the intended dose was given and resulted in prolonged neuromuscular blockade. The block was unresponsive to calcium and the recovery observed after edrophonium and neostigmine was so slow that it may have been unrelated to their administration. Adequate neuromuscular function did not occur for nine hours. Although intravenous doses of clindamycin up to $4.8 \mathrm{~g}$ have been described, the recommended maximum daily dose is 2.7 g. ${ }^{6}$ Thus, although the dose administered was large and greater than intended, it was not outside previous experience. The prolonged neuromuscular blockade occurred in the absence of non-depolarizing relaxants except for a small defasciculating dose of d-tubocurarine $(3 \mathrm{mg})$ and the clindamycin was given 10-15 min after full clinical recovery from succinylcholine had been demon- 
strated. Thus, it appears that the block was due predominantly to clindamycin rather than to an interaction of clindamycin with neuromuscular relaxants to potentiate neuromuscular blockade.

There are many reports of neuromuscular actions of antibiotics either alone or in combinations with neuromuscular blocking drugs. ${ }^{2-5,7}$ The most common reports involve the aminoglycosides ${ }^{8,9}$ (neomycin, tobramycin, amikacin, gentamicin, and streptomycin); polypeptides ${ }^{10}$ (polymyxin B); tetracyclines; and to miscellaneous drugs including vancomycin, ${ }^{11}$ and lincomycin. Fogdall and Miller reported that the neuromuscular block in a patient after pancuronium ( $2 \mathrm{mg}$ ) was prolonged for $20 \mathrm{hr}$ after chloramphenicol $(500 \mathrm{mg})$ and clindamycin phosphate $(600 \mathrm{mg})$. The prolonged block, which was assumed to have been caused by clindamycin, showed no response to neostigmine and calcium was not administered. ${ }^{2} \mathrm{Je}-$ deiken et al. reported a block lasting for three hours after vecuronium ( $4 \mathrm{mg}$ ) followed by gentamycin $(120 \mathrm{mg})$ and clindamycin $(1200 \mathrm{mg})$. Some improvement seemed to occur after neostigmine. ${ }^{3}$ Both reports described potentiation of non-depolarizing block. Intensification of recovering blocks have previously been described following the administration of vancomycin to a patient who was recovering from succinylcholine-induced neuromuscular block. ${ }^{12}$ The authors suggested that the presence of phase II block at the time of administration of vancomycin was important in the ensuing paralysis. A similar recurrence of neuromuscular blockade requiring controlled ventilation has been described when sternal irrigation with polymyxin/amikacin was given to a patient in whom spontaneous ventilation had resumed after reversal of vecuronium-induced block with neostigmine. ${ }^{13}$ However, in the present case, there was no evidence of residual neuromuscular block at the time of administration of clindamycin.

The mechanism of antibiotic-induced neuromuscular block is only partly understood and the response to attempted reversal with calcium or anticholinesterases is variable. Experiments in the mouse phrenic nervediaphragm preparation ${ }^{14}$ showed that the polymyxins were the most potent neuromuscular blocking antibiotics followed by the aminoglycosides (neomycin, streptomycin, gentamicin and kanamycin). Clindamycin, erythromycin, penicillin $\mathrm{V}$, and tetracycline produced neuromuscular block but at low concentrations there was initial twitch augmentation. Clindamycin phosphate was the least active of all the antibiotics tested and was one-tenth as potent as clindamycin hydrochloride. In the same study it was shown that calcium antagonised, at least in part, the block produced by aminoglycosides, polymyxin, lincomycin and tetracycline but had no effect on muscle paralysis induced by clindamycin. Similarly, anticholin- esterases induced some recovery after aminoglycosides but none after clindamycin. Thus, it appears that the block produced by the aminoglycosides resembles that of magnesium which is known to decrease the release of acetylcholine ${ }^{15}$ and also reduces post-junctional sensitivity. The actions of other antibiotics are less clear. However, clindamycin appears to cause muscle relaxation predominantly by a direct action on contractility ${ }^{5}$ rather than by inhibition of neuromuscular transmission. However, the fade in response to TOF and TET stimulation, as seen in our patient, suggests that it also has some pre-synaptic activity. ${ }^{16}$ When clindamycin was added to the guinea pig lumbrical muscle-nerve preparation, it produced neuromuscular blockade in concentrations of $180-240 \mu \mathrm{g} \cdot \mathrm{ml}^{-1},{ }^{17}$ which is similar to the concentrations anticipated to have occurred in the present case if it is assumed that the volume of distribution is approximately $0.66 \mathrm{~L} \cdot \mathrm{kg}^{-1}$.?

This case demonstrates that when clindamycn is given in doses of $40 \mathrm{mg} \cdot \mathrm{kg}^{-1}$ it may be followed by profound and prolonged neuromuscular block even when it is given in the absence of clinical neuromuscular blockade. The block cannot be reversed with calcium or anticholinesterases. Thus, the recommended management is supportivecontrolled ventilation until neuromuscular blockade has resolved spontaneously.

\section{References}

1 Wright JM, Collier B. Characterization of the neuromuscular block produced by clindamycin and lincomycin. Can J Physiol Pharmacol 1976; 54: 937-44.

2 Fogdall RP, Miller RD. Prolongation of a pancuroniuminduced neuromuscular blockade by clindamycin. Anesthesiology 1974; 41: 407-9.

3 Jedeikin R, Dolgunski E, Kaplan R, Hoffman S. Prolongation of neuromuscular blocking effect of vecuronium by antibiotics. Anaesthesia 1987; 42: 858-60.

4 de Gouw NE, Crul JF, Vandermeersch E, Mulier JP, van Egmond J, Van Aken $H$. Interaction of antibiotics on pipecuronium-induced neuromuscular blockade. J Clin Anesth 1993; 5: 212-5.

5 Sokoll $M D$, Gergis SD. Antibiotics and neuromuscular function. Anesthesiology 1981; 55: 148-59.

6 United States Pharmacopeia. Drug Information for the Health Care Profession. Taunton, Mass: Rand McNally, 1994: 862-4.

7 Pittinger CB, Eryasa Y, Adamson R. Antibiotic induced paralysis. Anesth Analg 1970; 49: 487-501.

8 Pridgen JE. Respiratory arrest thought to be due to intraperitoneal neomycin. Surgery 1956; 40: 571-4.

9 Dupuis JY, Martin R, Tétrault J-P. Atracurium and vecuronium interaction with gentamicin and tobramycin. Can J Anaesth 1989; 36: 407-11. 
10 Fogdall RP, Miller RD. Prolongation of a pancuroniuminduced neuromuscular blockade by polymyxin B. Anesthesiology $1974 ; 40: 84-7$.

11 Huang $K C$, Heise A, Shrader AK, Tseuda $K$. Vancomycin enhances the neuromuscular blockade of vecuronium. Anesth Analg 1990; 71: 194-6.

12 Albrecht RF II, Lanier WL. Potentiation of succinylcholine-induced phase II block by vancomycin. Anesth Analg 1993; 77: 1300-2.

13 Kronenfeld MA, Thomas SJ, Turndorf $H$. Recurrence of neuromuscular blockade after reversal of vecuronium in a patient receiving polymyxin/amikacin sternal irrigation. Anesthesiology 1986; 65: 93-4.

14 Singh $Y N$, Harvey $A L$, Marshall IG. Antibiotic-induced paralysis of the mouse phrenic nerve-hemidiaphragm preparation, and reversibility by calcium and by neostigmine. Anesthesiology 1978; 48: 418-24.

15 del Castillo J, Engbaek $L$. The nature of the neuromuscular block produced by magnesium. J Physiol (Lond) 1954; 124: 370-84.

16 Bowman WC. Prejunctional and postjunctional cholinoceptors at the neuromuscular junction. Anesth Analg 1980; 59: 935-43.

17 Becker $L D$, Miller $R D$. Clindamycin enhances a nondepolarizing neuromuscular blockade. Anesthesiology 1976; 45: 84-7. 